\title{
Occupational hazards in hospitals: risk of infection
}

\author{
J J GESTAL \\ From the Department of Preventive and Social Medicine, Faculty of Medicine, University of Santiago, \\ Santiago de Compostela, Spain
}

ABSTRACT: In this review of the risk of infection to hospital staff, attention is drawn to the continuing risk presented by hepatitis B and pulmonary tuberculosis, which are more common than diseases such as typhoid fever, brucellosis, histoplasmosis, whooping cough, infectious gastroenteritis, measles, and parotiditis. Other items considered include the susceptibility of female hospital staff to rubella and the importance of their undergoing screening and vaccination; the risks currently presented by epidemic keratoconjunctivitis and by herpes viruses (herpes simplex, varicella zoster, and cytomegalovirus); and the risk of contracting the new infectious diseases (Legionnaires' disease, Marburg disease, Lassa fever, and the acquired immune deficiency syndrome).

The social pressures that first led to legislation regarding protection against occupational hazards resulted from the efforts of many health workers in occupational pathology. Paradoxically, however, health workers often display relatively little concern about the occupational hazards to which they themselves and their colleagues are exposed, though certain dangers were pointed out as early as 1700 in chapter XIX of Ramazzini's De Morbis Artificum Diatriba. ${ }^{1}$ Despite the many serious dangers present in hospitals and medical research centres, health and safety regulations are frequently ignored. Indeed, hospital staff at times act as though their medical knowledge and their being surrounded by fellow professionals make protective measures unnecessary. Alternatively, certain hazards, notably the risk of infection (whose many victims include such figures as Louis Thillier, Otto Obermeir, Lazear, John E Dutton, Kolletscka, Allan Macfadyen, Ricketts, and Von Prowasek), are considered as an unavoidable part of medical practice and research. ${ }^{2}$ Finally, the desire to make use of novel techniques in the fight against disease before their possible pathogenic effects have been investigated has not infrequently led to both the doctor and his family being placed at risk. Well known examples of this last phenomenon are the early use of ionising radiation, cytostatics, and anaesthetic gases, the latter having been blamed for the chronic nephritis that led to the premature death at the age of 45 of John Snow.

Although hazards exist wherever health care is practised, the greatest risks are undoubtedly run by the staff of hospitals and research centres. The economic consequences of occupational disease and injury in hospitals may be measured in terms of the number of working days lost due to temporary sickness and the cost of the lost days together with the cost of medical attention, compensation, and pensions. From the moral point of view, the consequences go further than the economic, physical, and psychological damage to the worker and his family (including the increased frequency of abortions, congenital malformations, premature births, underweight babies, and perinatal deaths), and together constitute a possible threat from an increase in the mutation rate. Awareness of the gravity of the problem has led the World Health Organisation to set up a working group on occupational hazards in hospitals, whose recommendations ${ }^{3}$ are summarised in table 1 .

\section{Exposed population and the classification of hazards}

In the United States the health sector is a "growth industry"; in the United Kingdom one in 20 workers is employed by the National Health Service and in France there were an estimated 350000 employees in public hospitals in 1977. In Spain and other countries the hospital is the chief employer of labour in many cities. Furthermore, the fact that nearly two thirds of hospital staff are women whose professional life lasts only about five years on average means that the number of people exposed at some time to occupational hazards in hospitals is considerably larger than the number of workers at any given moment. Hospital personnel may be divided into two categories: health workers proper-that is, medical 
Table 1 Recommendations of the $\mathrm{WHO}$ working party on occupational hazards in hospitals (The Hague, 20-22 October 1981)

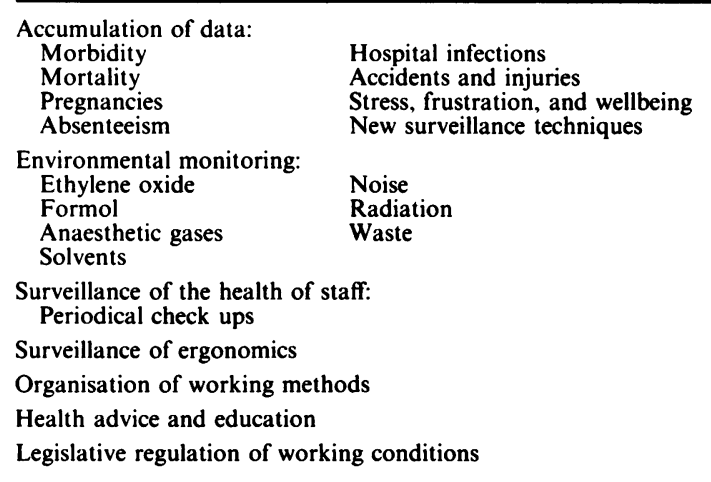

Table 2 Distribution of hospital personnel

\begin{tabular}{|c|c|c|}
\hline Category & France $^{4 *}$ & $\begin{array}{l}\text { Hospital General de } \\
\text { Galicia }^{5}\end{array}$ \\
\hline $\begin{array}{l}\text { Health workers proper } \\
\text { Auxiliary staff: }\end{array}$ & $68 \cdot 7 \%$ & $71 \cdot 4 \%$ \\
\hline $\begin{array}{l}\text { Technical and general } \\
\text { Administrative }\end{array}$ & $\begin{array}{r}23 \cdot 3 \% \\
8 \cdot 0 \%\end{array}$ & $\begin{array}{r}20 \cdot 6 \% \\
7.7 \%\end{array}$ \\
\hline
\end{tabular}

*Based on a review of 170000 hospital employees.

and paramedical staff directly attending the patient or collaborating in the diagnosis of disease-and auxiliary staff (cooks, butchers, bakers, gardeners, bricklayers, labourers, painters, plumbers, boilermen, electricians, laundrywomen, sempstresses, porters, messengers and administrative staff). The latter, who generally make up about $30 \%$ of the total hospital workforce (table 2) are exposed to both the hazards intrinsic to their own trades and to those faced by the health workers proper, albeit less intensely. Thus the administrative staff dealing with admissions, orderlies, meals distributors, and cleaners all enter into contact with patients, whereas electricians and mechanics may be exposed, for example, to ionising radiation.

The main hazards to which health workers proper are exposed may be classified as follows: (1) infection, (2) accident, (3) radiation, (4) exposure to noxious chemicals, (5) drug addiction and psychological problems, and (6) assault.

In the remainder of this paper we shall examine the first category, the risk of infection; the other classes of hazard will be discussed elsewhere.

\section{Risk of infection}

The risk of infection, historically the first to be recog- nised, is testified by the many health workers whoz over the years have lost their lives in the fight agains disease, to the point that society as a whole to some extent accepts such losses as an inevitable con sequence of medical research or practice. Thougho present in all medical environments, the greatest riskso arise in hospital and germ research centres, especially in areas such as laboratories, infectious disease wards $\widehat{\Phi}$ and paediatric departments, or during procedureș such as bronchoscopy, and it is the class of health ${ }^{\text {s }}$ workers proper that is the most frequently affected. 20 Though occupational disease may be produced by any type of pathogenic micro-organism to which the health worker is exposed, we shall necessarily restric our attention to a discussion of the most common or 3 most threatening.

Among the infectious occupational diseases to which the health worker is prone, that which offersi the most serious threat overall is undoubtedly hepa fr titis B. Much has been written recently on the subjec? of hepatitis B in health workers, and I shall limitmyself here to outlining the general problem. The risk of contracting the disease is particularly great during the first few years of medical practice and in thoseo departments in which there is frequent contact with blood (haemodialysis units, operating theatres and anaesthetic rooms, blood banks, and laboratories) The fact that many patients entering hospital ${ }^{3}$ for other reasons are hepatitis $\mathrm{B}$ carriers makes the risk presented by this disease greater than it would be otherwise, and justifies strict safety procedures for the manipulation of all blood samples or suspect body, fluids, especially when the patient belongs to high prevalence groups such as drug addicts, homosexuals haemophiliacs, patients undergoing haemodialysis, or residents in high prevalence areas. The available means of preventing infection nowadays include not only physical and chemical barriers (the use of gloves and disposable syringes and needles and disinfectionwith $0.5 \%$ sodium hypochlorite) but also biologicap barriers (hyperimmune gammaglobulin and vac ${ }^{2}$ cines). Vaccination is the least expensive preventive measure and should be offered to all health workers $>$ or at least those working in high risk areas. Thougle. the cost of present day vaccines is still too high to allow their widespread use (the Spanish government, for example, has had to limit their prescription), $\sec _{0}^{\text {O }}$ ond generation vaccines produced by cloning gen $N$ etically modified yeasts or by laboratory synthesis of surface antigen proteins should soon allow cheap mass produced vaccines to be used on a large scale in countries with high rates of hepatitis B and? hepatocellular carcinoma.

Of the bacterial diseases likely to be contracted by health workers as a result of their professional activ@ ity, the danger presented by pulmonary tuberculosis 
is still the most noteworthy. The first quantitative estimate of the risk of catching this disease was made in 1957 by Reid, ${ }^{6}$ who, in a prospective study of 345 English laboratories between 1940 and 1953, found that the risk of contracting tuberculosis was several times higher among pathologists than among a comparable sample of postmen. These results were confirmed 20 years later by Harrington. ${ }^{7-11}$ Nowadays, the greatest hazard is not presented by patients under treatment for tuberculosis but by patients not suspected of suffering from the disease who are admitted to hospital for other reasons. Both these patients themselves and their pathological products may act as sources of contagion: Claver et al obtained positive diagnoses of tuberculosis for $0.91 \%$ of samples from biopsies and postmortem examinations ${ }^{12}$; and among 39835 biopsies and extirpated tissues examined in Cordoban hospitals between 1978 and 1982 by Garcia Barbero et al positive diagnoses were obtained in 115 cases $(0 \cdot 29 \%)$, in $59(51 \cdot 3 \%)$ of which tuberculosis had not been suspected. ${ }^{13}$ In the United Kingdom 38 cases of pulmonary tuberculosis were diagnosed by positive cultures among health workers in the year 1981-2, 18 of the patients being nurses or doctors.

Most types of food borne infectious gastroenteritis occurring in the community also crop up in hospitals, the best documented cases having been outbreaks of salmonellosis. ${ }^{14-26}$ Whooping cough has low infection and morbidity rates among adults and is generally limited to a slight respiratory illness, the risk of acquiring it being too small to justify systematic vaccination even in paediatric departments, whose staff are the most exposed. ${ }^{27}$ The fact that typhoid fever, brucellosis, and histoplasmosis have occasionally been picked up by laboratory staff or students as a consequence of strains of these micro-organisms having been used for quality control or with educational intent ${ }^{1128-30}$ poses the question of whether it is correct for pathogens to be used for such purposes.

On various occasions hospitals and health centres have been affected by Legionnaires' disease. ${ }^{31-33}$ In July 1968 , for instance, $95 \%$ of the personnel working in a building of the Oakland County Health Department in Pontiac (Michigan) caught the illness then christened "Pontiac fever."34-36 Another important outbreak among the patients and staff of the Wadsworth Medical Center in Los Angeles between May 1977 and July 1978 produced 49 cases, 15 of whom died. ${ }^{37}$ The probable sources of infection in at least some of these outbreaks were aerosols produced from recycled or stagnant water contaminated with Legionnaire pneumophila in air conditioning cooling towers and by sprinklers in showers and taps. The dangers ever present in pathology laboratories are nevertheless exemplified by the case of Dr Sheila
Katz of the Atlanta Center for Disease Control, who in 1976 was accidentally contaminated when handling infected lungs from patients who had died of atypical pneumonia.

Rubella is continually being introduced inadvertently into hospitals, the areas of highest risk being obstetric and paediatric departments and serological and microbiological laboratories. Its importance lies in the high risk of it causing congenital malformation or absorption if contracted by pregnant women during the first few months of gestation. About $6 \cdot 1 \%$ of pregnant women within the area of influence of the Hospital General de Galicia $^{38}$ and $5 \cdot 69 \%$ of its female staff ${ }^{39}$ are susceptible to rubella and similar percentages have been reported by the Hospital Clínico de Sevilla. ${ }^{40}$ The most appropriate preventive measures consist in the serological screening of all female staff of child bearing age and the vaccination of those found to be susceptible. Vaccination of susceptible men has also been recommended. Measles is a much less serious threat than rubella because only a small proportion of adults are susceptible. The risk of contracting parotiditis is also small, ${ }^{4142}$ though it might be worth while offering Jeryl-Linn vaccine ${ }^{43}$ to paediatric staff, who are the most exposed. Paediatric workers are likewise frequently affected by respiratory syncitial virus. ${ }^{44-47}$

Two adenovirus diseases affecting health workers are pharyngoconjunctival fever ${ }^{4849}$ and, much more commonly, epidemic keratoconjunctivitis, ${ }^{5051}$ which is transmitted by fingers ${ }^{52}$ and ophthalmological instruments or fluids ${ }^{53-5657}$ which have been contaminated by patients' ocular secretions. Outbreaks of keratoconjunctivitis are relatively common at first aid posts treating eye injuries and in ophthalmological consulting rooms. ${ }^{58-62}$ Between February and May 1984, for example, 145 cases originated in an ophthalmological department in Madrid (seven of them among the staff) ${ }^{63}$ and a similar outbreak occurred the same year in the province of Pontevedra.

Of the herpes viruses, ${ }^{64}$ herpes simplex produces whitlows and herpetic paronychia, especially among the doctors and nurses of intensive care units, odontological departments, and the anaesthetic service, who are the most exposed to patients with infected oral secretions. ${ }^{65-69}$ These complaints may be painful and ugly but there is no evidence of their being actually dangerous for otherwise healthy individuals. Fetuses, however, are at risk, especially during the first three months of gestation when there is most danger of congenital defects.

There is little risk of health workers becoming infected with varicella zoster because few adults are susceptible (figures of $3 \cdot 2 \%^{70}$ and $2 \cdot 6 \%{ }^{71}$ have been published), but in those cases that do arise the illness presents with more complications than in children. 
Infection during pregnancy may, occasionally, have teratogenic effects on the fetus during the first three months and transplacental infection may occur in the final weeks of gestation.

Infection by varicella zoster may be prevented by physical and chemical barriers and by biological barriers in the form of specific immunoglobulin (which should be administered as soon as possible after exposure, and in any case before 96 hours have passed ${ }^{72}$ ) and the attenuated live vaccines $\mathrm{KM}_{c} \mathrm{C}^{73}$ and OKA. ${ }^{74-79}$

There is less evidence that cytomegalovirus ${ }^{8081}$ has the same capacity as rubella to produce outbreaks in hospital but it is the commonest cause of congenital infections $\left(0.4-2.0 \%\right.$ of all live newborn babies). ${ }^{82}$ Classic cytomegalic inclusion disease is rare (1 case per 3000-5000 births) but congenital infection by cytomegalovirus (the clinical signs of which are similar to those of congenital infection by toxoplasma, rubella, or herpes simplex) occurs in about $1 \%$ of births, with serious sequelae in $10 \%$ of the affected infants. ${ }^{8384}$ Little is known concerning the risk of cytomegalovirus being transmitted to adults caring for these children (it would be particularly desirable to know the risks to women of child bearing age in hospitals, nurseries, schools, and other institutions) but it is probably small and no greater for paediatric workers than for the general population. ${ }^{85-87}$ Seroepidemiological studies indicate that infection commonly occurs in infancy, though the observed increase in seroconversion rates at puberty suggests transmission through sexual intercourse and kissing. Annual seroconversion rates among adults with high occupational risk range from 0 to $7 \cdot 7 \%,{ }^{8688} 89$ as compared with the $10 \cdot 3 \%$ seroconversion rate among children and the $53 \%$ attack rate within families. These figures suggest that transmission requires prolonged close contact and that the occupational hazard, if any, is slight. There nevertheless remains the theoretical possibility of a susceptible pregnant woman catching the disease from a child excreting viruses in urine or through the upper respiratory tract, and prudence recommends certain precautions being taken. ${ }^{64}$

Although there is no statistical evidence to suggest that health workers are more likely to contract Creutzfeld-Jakob disease than others, it is worth mentioning a possible case reported by Traub et $a l^{90}$ and Gajdusek et al. ${ }^{91}$ In 1974 the brain of a neurosurgeon who had died from an illness unrelated to CreutzfeldJakob disease was found to exhibit the pathological alterations characteristic of this disease, which was furthermore transmitted to a primate. It is not known whether the surgeon in question had ever operated on a patient suffering from transmissible dementia, but the possibility clearly exists. No cases of infection have been reported among laboratory personnel afte 10 years of handling the Creutzfeld-Jakob virus ${ }^{92}$ of after 20 years of working with the kuru virus. ${ }^{93}$ The same type of preventive measures as are used agains $\$$ hepatitis B should nevertheless be observed. The pose sibility of contracting smallpox in the laboratory and the consequent risk of its propagation among hospitas? staff and inmates will persist so long as variola viruse are preserved in collections. A year after the last case of endemic smallpox, which was recorded in Merca (Somalia) on 25 October 1977, came the outbreak aP the East Birmingham Hospital on 24 August $1978 \overrightarrow{\vec{\omega}}$ Nor should the threat of smallpox being used as military weapon be forgotten. Vaccination is nevero theless only justified at present among research stafB working with orthopoxvirus or personnel engaged in the production of antismallpox vaccine.

At the same time as some of the infectious diseases traditionally affecting man have been dealt with andr contained others have taken their place. Legiono naires' disease has already been mentioned; other new infectious diseases include viral haemorrhagic fevers such as Marburg disease, whch caused seven deaths among the 31 cases registered in Germany ando Yugoslavia in 1976. This epidemic originated among laboratory staff who had handled the blood and tissues of green monkeys (Cercopithecus aethiops imported from Uganda, subsequent cases arising among patients with whom these workers had had contact. $^{9495}$ Other viral infections that havo appeared in recent years include the Ebola virus which is highly contagious by contact and has a high mortality rate; Lassa fever, ${ }^{96} 97$ caused by an adena 5 virus that is likewise extremely pathogenic for man under hospital and laboratory conditions ${ }^{98-101}$ haemorrhagic Crimea-Congo fever, reported to have् been contracted by hospital personnel after contace with patients' blood ${ }^{102}$; and haemorrhagic fever with renal syndrome reported in laboratory staff who had handled rats spontaneously infected with Hantaan virus. ${ }^{103-105}$ In all such cases special safety measures must be used both in the care of patients and in carry ing out laboratory tasks.

The infectious disease currently giving rise to mose anxiety among both hospital workers and the generaN population is perhaps the acquired immune deficiency syndrome (AIDS). Hospital staff have not been reported as being more at risk than others, ${ }^{106}$ and although their undoubted concern about AIDS has been increased by the discovery of asymptomatic caro riers and by the virus having been isolated fron saliva, ${ }^{107}$ tears, ${ }^{108}$ and contact lenses, ${ }^{109}$ there is ${ }^{+}$ nevertheless little risk of the AIDS virus being transmitted by these routes. ${ }^{110111}$ It is rare for the virus to be present in the saliva of those infecs ted, ${ }^{112113}$ and if present the quantities are small an\& 
non-infectious. Saviteer et al, for example, have reported that two nurses who took part in mouth to mouth resuscitation of a patient with AIDS neither fell sick nor suffered seroconversion ${ }^{144}$; and there have been no reports of AIDS having been passed on by a patient with AIDS to housemates exposed to saliva and tears but with whom there has been no sexual intercourse. ${ }^{115-117}$ It may therefore be concluded that AIDS is transmitted chiefly by sexual contact, injection of contaminated blood, or from mother to fetus, other mechanisms being extremely rare. ${ }^{118}$

None of the health workers subjected to prospective surveillance by the Atlanta Center for Disease Control since August 1983 has developed signs or symptoms suggestive of AIDS, and although 278 of the 8218 cases of AIDS notified to the CDC up to 11 February 1985 were health workers (3\%), all except $24(9 \%)$ belonged to known high risk groups, and of the 24 exceptions, six of the 17 cases investigated were probably due to non-occupational exposure (in the remaining 11 cases no infective risk factors were identified, though specific occupational exposure to patients with AIDS or suspects may not have been recorded). ${ }^{119}$ These negative findings are corroborated by those of McGray et al, ${ }^{120}$ who likewise failed to discover AIDS among hospital workers attending patients with AIDS in the United States. No reported case of AIDS among hospital staff has been preceded by the patients attending another patient with AIDS professionally. ${ }^{120-122}$ The only confirmed case of the AIDS virus being acquired by a hospital worker as the result of her work was a British nurse in whom seroconversion was detected 49 days after she was accidentally injected with traces of the blood of a patient with AIDS. ${ }^{123}$ In 1984 Belani et al also reported the case of a 33 year old black male hospital cleaner who belonged to none of the known high risk groups and apparently had no contact with any patient with AIDS known in the hospital but who began to exhibit signs of AIDS 14 months after prophylactic gammaglobulin had been administered after his accidentally pricking himself with a needle $^{124}$; however, there have been many cases of AIDS in which it has been impossible to identify any known risk factor ${ }^{120} 125$ and the mere fact of the accidental prick having preceded the onset of AIDS is insufficient for this case to be attributed to occupational hazard. In the United States two other cases of hospital workers being pricked by bloodstained needles before acquiring the virus have been reported ${ }^{126127}$ but in these cases too it was impossible to prove conclusively that these accidents were in fact the means of transmission; and several clinical, immunological, and serological studies of groups of hospital workers who were either in frequent contact with patients with AIDS or their biological products or who had been pricked or soiled with blood from patients with confirmed AIDS have failed to discover any cases of AIDS or seroconversion among the subjects studied.124128-134 Gerberding et al have reported the case of a bronchioscopist who, on pricking himself with a needle contaminated by lung tissue from a patient with AIDS acquired hepatitis B, which showed itself 15 weeks later (no prophylactic measures had been taken) but in whom no immune response to HTVL-III virus could be detected even after 15 months. ${ }^{135}$

Perhaps the low incidence of transmission of AIDS by needle pricks (one case of seroconversion in over 650 accidents $^{136}$ as against an acquisition rate of $20-30 \%$ in the case of hepatitis B) may be due to the low concentration of infectious particles in the blood $\left(10^{4}\right.$ viral particles per millimetre as against $10^{13}$ in the case of hepatitis B). ${ }^{137}$ Medical and paramedical staff in contact with patients with AIDS or their biological products should nevertheless scrupulously observe the hygienic recommendations of the University of California, the Atlanta Center for Disease Control, the Hospital Infection Society Working Party on AIDS, ${ }^{137-145}$ and others, ${ }^{146-148}$ which are basically identical to those laid down for hepatitis B. It should also be remembered that, as Das et al have pointed out, the risk of AIDS being contracted by hospital staff during the course of their duties derives not only from contact with samples from infected patients but also from the use of commercial products prepared by pooling the sera of many individuals. ${ }^{149}$

\section{RISK OF INFECTION IN THE LABORATORY}

The laboratory is for many reasons an area of particularly high risk. Procedures such as centrifugation, the opening of culture vessels, or the seeding of agar plates favour the formation of aerosols that may be inhaled 150-152; the use of oral pipettes and the habits of smoking, eating, or drinking in the laboratory involve the risk of ingesting pathogens; and the use of needles and the unwary handling of animals brings with it the risk of cutaneous inoculation. Observance of correct microbiological procedures and the use of safety equipment nevertheless greatly reduce the risk of infection in the laboratory. Most laboratories in developed countries have codes of good practice in the form of either voluntary recommendations or legal requirements, ${ }^{153}$ and as part of its special programme on safety measures in microbiology the WHO has recently published a biological safety manual for laboratories. ${ }^{154}$

Measures for the prevention of infection among health workers may thus be summed up as follows.

(1) Susceptible members of the staff should be identified by means of periodic check-ups. 
(2) Subjects susceptible to diphtheria, tetanus, hepatitis B, and rubella should be immunised and possibly those susceptible to influenza, parotiditis, and measles also.

(3) All personnel should be taught and trained in safety measures.

(4) Codes of practice should be adopted.

(5) The architectural design of laboratories should be suited to their function.

(6) Appropriate isolation and disinfection measures should be applied both to the material handled and the environment in which it is handled.

(7) An epidemiological system for the surveillance of infection among hospital workers should be set up.

\section{References}

1 Ramazzini B. Tratado de las enfermedades de los artesanos. Madrid: INSALAD Ministerio de Sanidad y Consumo, 1983.

2 Gestal Otero J. Riesgos laborales en el hospital:riesgo infeccioso. Libro de Actas del Tercer Congreso Nacional de Higiene y Medicina Preventiva Hospitalaria. Salamanca: Cátedra de Medicina Preventiva y Social, Universidad de Salamanca, 1985:161-73.

3 Organización Mundial de la Salud. Grupo de trabajo sobre riesgos profesionales en hospitales. Rev San Hig Pub 1982;56:1253-60.

4 Oficina Internacional del Trabajo. Enciclopedia de medicina, higiene $y$ seguridad del trabajo. Vol I-II. Madrid: Ministerio de Trabajo, Instituto Nacional de Previsión, 1974.

5 Gestal Otero JJ, Sureda Santiso MD, Belio Blasco C, Alvarez Perez M. Etiologia del absentismo laboral hospitalario. Medicina y Seguridad del Trabajo 1982;119:145-58.

6 Reid DD, The incidence of tuberculosis among workers in medical laboratories. Br Med J 1957;iii:1-4.

7 Harrington JM, Shannon HS. Sickness absence in medical laboratories. In: Proceedings of XVIIIth International Congress on Occupational Health, Brighton, 1975.

8 Harrington JM, Shannon HS. Incidence of tuberculosis, hepatitis, brucellosis, and shigellosis in British medical laboratory workers. $\mathrm{Br} \mathrm{Med}$ J 1976;i:759-62.

9 Harrington JM, Shannon HS. Survey of safety and health care in British medical laboratories. $\mathrm{Br}$ Med J 1977;i:626-8.

10 Harrington JM. The occupational hazards of medical laboratory work. Laboratory Practice 1980;29:626-9.

11 Harrington JM. Health and safety in medical laboratories. Bull WHO 1982;1:9-16.

12 Claver M, Ruiz A, Contreras F. El problema de la tuberculosis estudiada a traves de un servicio general de anatomia patológica. Patologia 1971;4:195-206.

13 Garcia Barbero MD, López Beltrán A, Cisnal A, Toro M, Collantes E, Ramón y Cajal $S$. Incidencia de tuberculosis en material anatomopatológico de los hospitales de Córdoba. Enfermedades Infecciosas y Microbiologia Clínica 1985;5:197-200.

14 Schroeder SA, Aserkoff B, Brachman PS. Epidemic salmonellosis in hospitals and institutions: a five-year review. $N$ Engl $J$ Med 1968;279:674-8.

15 Anonymous. Enfermedades infecciosas intestinales 1983. Boletin Epidemiológico Semanal. Madrid: Ministerio de Sanidad y Consumo. Dirección General de Salud Pública, 1983;1618:369.

16 Anonymous. Brotes de infecciones e intoxicaciones alimentarias. España 1983 (I). Boletín Epidemiológico Semanal. Madrid: Ministerio de Sanidad y Consumo, Dirección General de Salud Pública, 1984;1631:81-3.

17 Anonymous. Brotes de infecciones e intoxicaciones de origen alimentario. España 1984 (ler semestre). Boletin Epidemiológico Semanal. Madrid: Ministerio de Sanidad y Consumo. Dirección General de Salud Pública, 1984;1650:233-5.

18 Anonymous. Brotes de toxiinfección alimentaria en 1982. Boletin Epidemilógico Semanal. Madrid: Ministerio de Sanidad y Consumo. Dirección General de Salud Pública, 1983;1584:109-11.

19 Anonymous. Brotes de infecciones $\mathrm{e}$ intoxicaciones alimentarias. España 1983 (II). Boletín Epidemiológico Semanal. Madrid: Ministerio de Sanidad y Consumo. Dirección General de Salud Pública, 1984;132:89-91.
20 Anonymous. Vigilancia de toxiinfecciones alimentarias. Reino Unido y Francia. Boletín Epidemiológico Semanal. Madrid: Ministerio de Sanidad y Consumo. Dirección General de Salud Pública, 1982;1550:201-3.

21 Baine WB, Gangarosa EJ. Institutional salmonellosis. J Infect Dis 1973;128:357.

22 Datta N, Pridie RB. An outbreak of infection with salmonella typhimuriumin a general hospital. J Hyg (London) 1958;58:229.

23 Sweeney FJ Jr, Randall EL. Clinical and epidemiological studies of salmonella derby infections in a general hospital. In: Proceedings of National Conference on Salmonellosis 11-13 March 1964. Washington: $\vec{\nabla}$ US Department of Health Education and Welfare, Public Health Service, Government Printing Office, 1965:130-9. (Publ No 1262.)

24 Sanders E, Sweeney FJ, Friedman EA, Boring JR, Randall EL, Polk LD. ఝ An outbreak of hospital associated infections due to salmonella derby. $\overrightarrow{\vec{D}}$ JAMA 1963;186:984-6.

25 Steere A, Hall W, Gangarsa EJ, et al. Person-to-person spread of salmonella typhimurium after a hospital common-source outbreak. $\omega$ Lancet 1975;i:319-21.

26 Bennett JV, Brachman PHS. Infecciones hospitalarias. Barcelona: EditorialO JIMS, 1982.

27 Linnemann CC Jr, Ramundo N, Perlstein PH, Minton SD, Englender GS. Use of pertussis vaccine in an epidemic involving hospital staff. Lancet 1975;ii:540-3.

28 Pike RM. Past and present hazards of working with infectious agents. Arch. Pathol Lab Med 1978:333-6.

29 Pike RM. Laboratory-associated infections: incidence fatalities, causes and prevention. Ann Rev Microbiol 1979;33:41-66.

30 Blaser MJ, Hickman FV, Farmer JJ III, Brenner DJ, Balows A, Feldman RA. Salmonella typhi: the laboratory as a reservoir of infection. $J$ Infect -

Dis 1980;6:934-8.
31 Gestal Otero JJ. Enfermedad de los legionarios, epidemiologia y profilaxis I. Medicina Galaica 1981;14:23-6.

32 Gestal Otero JJ. Enfermedad de los legionarios, epidemiologia y profilaxis $\overrightarrow{c o}$ II. Medicina Galaica 1981;15:6-18.

33 Fraser DW, Tsai TR, Orenstein W, et al. Legionnaires disease, description of an epidemic of pneumonia. N Engl J Med 1977;297:1189-97.

34 Anonymous. Epidemic of obscure illness: Pontiac, Michigan. MMWR 1968;17:315-20.

35 Fraser DW, Deubner DC, Hill DL, Guillian DK. Nonpneumonia shor incubation period legionellosis (Pontiac fever) in men who cleaned $a$ steam turbine condenser. Science 1978;205:690-1.

36 Gick TH, Gregg MB, Berman B, Mallison G, Rhodes WW Jr, Kassanoff $I \frac{\text { D }}{Q}$ Pontiac fever epidemic of unknown etiology in a health department. 1 . Clinical and epidemiological findings. Am J Epidemiol 1979;107:149-60. $\vec{F}$

37 Haley CE, Cohen ML, Halter J, Meyer RD. Nosocomial legionnaires? disease: a continuing common source epidemic at Wadsworth MedicaP Centre. Ann Intern Med 1979;90:583-6.

38 Boveda Fontan J, Gestal Otero JJ, Aguiar González-Redondo MR Seroepidemiologia de la rubeola en enmbarazadas del área de influencia del hospital general de Galicia. Infectologika 1983;5:259-67.

39 Cembrero Gil C, Sanchez Mozo R, Jiménez Martínez T, DominguezD Carmona M. Estudio del nivel inmunitario frente a la rubeola deb personal femenino en un hospital. Rev Med Univ Navarra 1976;1:99-106'

40 Cabacas T, Borobio MV, Alvarez JL, Palomares JC. Rubeola:estudio seroepidemiológica en Sevilla. Inmunologika 1981;2:58-61.

41 Ikeda S, Chiba S, Chiba Y, Nakao T. Epidemiological, clinical and serological studies on epidemic of mumps in an infant nursery, Tohoku. J Exp Med 1971;105:327-30.

42 St Geme JW Jr. Susceptibility of medical students to mumps: dubious value of currently available skin test antigens. Pediatrics 1972;49:314-5.

43 Benito Ruesca R, Gómez Lus R. Las vacunas: actualización y futuro Infectologika 1984;1:51-68.

44 Hall CB, Geiman JM, Douglas RG, Meagher MP. Control of nosocomia respiratory syncytial viral infections. Pediatrics 1978;62:728-32.

45 Sims DG, Downham APS, Webb JKG, Gardner PS, Weightman D. Hospital cross-infection on children's wards with respiratory syncytia virus and the role of adult carriage. Acta Paediatr Scand 1975;64:5114-44 N

46 Hall CB, Douglas RG, Geiman JM, Messner MK. Nosocomial respiratory 0 syncytial virus infections. N Engl J Med 1975;293:1343-6.

47 Ditchburn RK, McQuillin J, Garder PS, Courts BM. Respiratory syncytial virus in hospital cross-infection. Br Med J 1971;ii:671-3.

48 Faden H, Gallagher M, Ogra P, McLoughlin S. Nosocomial outbreak of pharyngoconjunctival fever due to adenovirus type 4. New Yor/S Morbidity and Mortality Report 1973;7.

49 Levandowsky RA, Rubenis M. Nosocomial conjunctivitis caused by 0 adenovirus type 4. J Infect Dis 1981;143:28-31.

50 Jawetz E, Hanna L, Nicholas A, et al. Some biological characteristics ofD adenovirus type 8. Am J Hyg 1958;67:276-85.

51 Hogan MJ, Crawford JW. Epidemic keratoconjunctivitis. Am J Ophthalmo 1942:25:1059-78. 
52 Laibson PR, Ortolan G, Dupre-Strachan S. Community and hospital outbreak of epidemic keratoconjunctivitis. Arch Ophthalmol 1968;80: 467-73.

53 Dawson C. Darrell $R$. Infections due to adenovirus type 8 in the United States. I. An outbreak of epidemic keratoconjunctivitis originating in a physician's office. N Engl J Med 1963;268:1031-4.

54 Mordhorst $\mathrm{CH}$, Kjer P. Studies on an epiden.ic of keratoconjunctivitis caused by adenovirus type 8 . I Virus isolation in human amniotic cells and serological observations. Acta Ophthalmol 1961;39:974-83.

$55 \mathrm{Kjer} \mathbf{P}$, Mordhorst $\mathrm{Ch}$. Studies on an epidemic of keratoconjunctivitis caused by adenovirus type 8 . II Clinical and epidemiological aspects. Acta Ophthalmol 1961;39:984-92.

56 Dawson CR. Hanna L, Wood TR, et al. Adenovirus type 8 keratoconjunctivitis in the United States. III Epidemiologic, clinical and microbiologic features, Am J Ophthalmol 1970;69:473-80.

57 Wood RM. Prevention of infection during tonometry. Arch Ophthalmol 1962;68:202-18.

58 Barnard DL, Deanhart JC, Marmion VJ, Clarke SKR. Outbreak in Bristo of conjunctivitis caused by adenovirus type $B$ and its epidemiology and control. Br Med J 1973;ii:165-9.

59 Dockburn TA, Nitowsky H, Robinson T, Cheever FS. Epidemic keratoconjunctivitis: study of small epidemic. Am J Ophthalmol 1953;36:1367-72.

60 Dawson C. Darrel R, Hanna L, Jawetz E. Infections due to adenovirus type 8 in the United States. II. Community-wide infection with adenovirus type 8. N Engl J Med 1963;268:1031-4.

61 Jawetz E, Hanna L, Sonne $M$, et al. A laboratory infection with adenovirus type 8: laboratory and epidemiologic observations. Am J Hyg 1959;69: 13-20.

62 Thygeson P. Epidemiology of epidemic keratoconjunctivitis. Trans Am Ophthalmol Soc 1948;46:366-85.

63 Anonymous. Queratoconjuntivitis epidémica. Boletín Epidemiológico Semanal. Madrid: Ministerio de Sanidad y Consumo. Dirección General de Salud Pública, 1985;1677:45-6.

64 Gestal Otero JJ. Riesgo de infección por herpes virus en profesionales sanitarios. Laboratorio 1985;6:381-96.

65 Bird T, Ennis JE, Wort AJ, Gardner PS. Diseminated herpes simplex in newborn infants. J Clin Pathol 1963;16:423-5.

66 Stern H, Elek SD, Millar DM, Anderson HF. Herpetic whitlow: a form of cross infection in hospitals. Lancet 1959;ii:871-4.

67 Adams G, Stover BH, Keenlyside RA, et al. Nosocomial herpetic infections in a pediatric intensive care unit. Am J Epidemiol 1981;113:126-32.

$68 \mathrm{Du}$ Moulin GG, Hedley-Whyte J. Hospital-associated viral infection and the anesthesiologist. Anesthesiology 1983;59:51-6.

69 Bart BJ, Fisher I. Primary herpes simplex infection of the hand: report of a case. J Am Dent Assoc 1965;71:74-7.

70 Shehab ZM, Brunell PA. Susceptibility of hospital personnel to varicellazoster virus. J Infect Dis 1984;150:786.

71 Lievens AW, Taylor-Wiedeman J, Brunell PA. Immunity of young adults to childhood diseases. Pediatr Res 1984;18:185.

72 Anonymous. Inmunoglobulina varicela-zoster en la prevención de la varicela. Boletín Epidemiológico Semanal. Ministerio de Sanidad y Consumo. Dirección General de Salud Pública, 1984;1660:313-5.

73 Arbeter AM, Starr SE, Weibel RE, et al. Live attenuated varicella vaccine: the KMcC strain in healthy children. Pediatrics 1983; 71:307-12.

74 Takahashi M, Otsuka T, Okuno Y, et al. Live vaccine used to prevent the spread of varicella in children in hospital. Lancet 1974;ii:288-90.

75 Katsushima N, Yazaki N, Sakamoto H, et al. Application of a live varicella vaccine to hospitalized children and its follow-up study. Biken $J$ 1982;25:29-42.

76 Bogger-Goren S, Baba K, Hurley P, et al. Antibody response to varicella zoster virus after natural or vaccine-induced infection. $J$ Infect $D$ is 1982;146:260-5.

77 Brunnell PA, Shehab Z, Geiser C, Waugh JE. Administration of live varicella vaccine to children with leukaemia. Lancet 1982;i:1069-72.

78 Gershon AA, Steinberg SP, Gelb L, et al. Live attenuated varicella vaccineefficacy for children with leukemia in remission. JAMA 1984;252:355-62.

79 Weibel RE, Neff BJ, Kuter BJ, et al. Live attenuated varicella virus vaccine. N Engl J Med 1984;310:1409-15.

80 Hamshaw JB. Cytomegalovirus. In: Remington JS, Klein JO, eds. Infectious diseases of the fetus and newborn infant. Philadelphia: WB Saunders Company, 1976:107-55.

81 Hanshaw JB, Dudgeon JA. Congenital cytomegalovirus. In : Schaffer AJ, Markowitz M, eds. Major problems in clinical pediatrics. Vol 17. Viral diseases of the fetus and newborn. Philadelphia: WB Saunders Company, 1978.

82 Stagno S, Pass RF, Dworsky ME, et al. Congenital cytomegalovirus. Clinical and epidemiologic characteristics in early infancy. $N$ Engl $J$ Med 1970;282:1075-8.

83 Hamshaw JB. Congenital cytomegalovirus infection. A fifteen year perspective. J Infect Dis 1971;123:555-61.
84 Stern H, Tucker SM. Prospective study of cytomegalovirus infection in pregnancy. Br Med J 1973;ii:268-70.

85 Ahlfors K, Ivarsson SA, Johnsson T, Remmarker K. Risk of cytomegalovirus infection in nurses and congenital infection in their offspring. Acta Paediatr Scand 1981;70:19-23.

86 Dworsky ME, Welch K, Cassady G, Stagno S. Occupational risk for primary cytomegalovirus infection among pediatric health-care workers. N Engl J Med 1983;309:950-3.

87 Yeager AS. Transmission of cytomegalovirus to mothers by infected infants: another reason to prevent transfusion-acquired infection. Pediatr Infect Dis 1983;2:295-7.

88 Hamberg B, Bertnes E, Hankenes G. Antibodies to,cytomegalovirus among personnel at a children's hospital. Acta Paediatr Scand 1980;69:407-9.

89 Yeager AS. Longitudinal serological study of cytomegalovirus infections in nurses and personnel without patient contact. J Clin Microbiol 1975;2: 448-52.

90 Traub RD, Gajdusek DC, Gibbs CJ Jr. Precautions in conducting biopsies and autopsies on patients with presenile dementia. $J$ Neurosurg 1974;41:394-5.

91 Gajdusek DC, Gibbs CJ Jr, Earle K, et al. Transmission of subacute spongiform encephalopathy to the chimpanzee and squirrel monkey from a patient with papulosis malgna of Köhlmeier-Degos. In: Proceedings of the 10th International Congress on Neurology, Barcelona 1973. Amsterdam: Burrows, EH, 1974;390-2. (International congress series No 319.)

92 Gibbs CJ Jr, Gajdusek DC, Asher DM, et al. Creutzfeldt-Jakob disease (subacute spongiform encephalopathy) transmission to the chimpanzee. Science 1968;161:388-9.

93 Gajdusek DC, Zigas V. Degenerative disease of the central nervous system in New Guinea: the endemic occurrence of kuru in the native population. N Engl J Med 1957;257:974-8.

94 Matini GA, Siegert R. Marburg virus disease. Berlin: Springer-Verlag, 1971

95 Simpson DIH. Infections $\dot{a}$ virus Marburg et Ebola: guide pour leur diagnostic, leur traitement et leur prophylaxie. Genèva: Organisation Mondiale de la Santé, 1977. (Publ offset, No 36.)

96 Frame JD, Baldwin JM, Gocke DJ, Troup JM. Lassa fever a new virus disease of man from West Africa. I. Clinical description and pathological finding. Am J Trop Med Hyg 1970;19:680-91.

97 White HA. Lassa fever: a study of 23 hospital cases. Trans $R$ Soc Trop Med Hyg 1973;22:773-9.

98 Monanth TP, Mertens PE, Patton R, et al. A hospital epidemic of Lassa fever in Zorzor, Liberia, March-April, 1972. Am J Trop Med Hyg 1973;22:773-9.

99 Mertens PE, Patton R, Baum JJ, et al. Clinical presentation of Lassa fever cases during hospital epidemic at Zorzor, Liberia, March-April, 1972. Am J Trop Med Hyg 1973;22:780-4.

100 Zweighaft RM, Fraser DW, Hattwick MAW, et al. Lassa fever: response to an imported case. $N$ Engl J Med 1977;15:803-7.

101 Anonymous. Lassa fever. Weekly Epidemiological Record 1985;15:115

102 Viral hemorrhagic fever surveillance: Congo-Crimean haemorrhagic fever Weekly Epidemiological Record 1984;40:331.

103 Umenai T, Lee HW, Lee PW, et al. Korean haemorrhagic fever in staff in an animal laboratory. Lancet 1979;i:1314-6.

104 Lee HW, Johnson KM. Laboratory-acquired infections with Hantaan virus, the etiologic agent of Korean haemorrhagic fever. J Infect Dis 1982; 146:645-51.

105 Desmyter J, Johnson KM, Deckers C, LeDuc JW, Brasseur F, Van Ypersele de Strihou C. Laboratory rat associated outbreak of haemorrhagic feve with renal syndrome due to Hantaan-like virus in Belgium. Lance 1982;ii:1445-8.

106 Geddes AM. Risk of AIDS to health care workers. Br Med J 1986;292:711-2.

107 Groopman JE, Salahuddin SZ, Sarngadharan MG, et al. HTLV-III in saliva of people with AIDS related complex and healthy homosexual me at risk from AIDS. Science 1984;226:447-9.

108 Fujikama LS, Palestine AG, Nussenblatt RB, Salahuddin SZ, Gallo RC. Isolation of human T-lymphotropic virus type III from the tears of a patient with the acquired immunodeficiency syndrome. Lancet 1985;ii:529-30.

109 Tervo T, Lahdevirta J, Vaheri A, Valle SL, Suni J. Recovery of HTLV-III from contact lenses. Lancet 1986;i:379-80.

110 Schechter MT, Boyko WJ, Douglas B, et al. Can HTLV-III be transmitted orally? Lancet $1986 ; \mathrm{i}: 379$.

111 Jeffries E, Willoughby B, Boyko WJ, et al. The Vancouver lymphadenopathy-AIDS study II: seroepidemiology of HTLV-III antibody. Can Med Assoc J 1985;132:1373-7.

112 Ho DD, Dyington RE, Schooley RT, Flynn T, Rota TR, Hirsch MS Infrequency of isolation of HTLV-III virus from saliva in AIDS. $N$ Engl J Med 1985;313:1606.

113 Levy JA, Kaminsky LS, Morrow JW, et al. Infection by retrovirus associated with the acquired immunodeficiency syndrome. Ann Intern 
Med 1985;103:694-9.

114 Saviteer SM, White GC, Cohen MS. HTLV-III exposure during cardiopulmonary resuscitation. $N$ Engl J Med 1985;313:1606-7.

115 Anonymous. Education and foster care of children infected with HTLVIII/LAV. MMWR 1985;34:517-21.

116 Redfield RR, Markham PD, Salahuddin SZ, et al. Frequent transmission of HTLV-III among spouses of patients with AIDS-related complex and AIDS. JAMA 1985;253:1571-3.

117 Friedland GH, Saltzman BR, Rogers MF, et al. Lack of transmission of HTLV-III/LAV infection to household contacts of patients with AIDS or AIDS-related complex with oral candidiasis. $N$ Engl J Med 1986;314: $344-9$.

118 Anonymous. Prospective evaluation of health case workers exposed via the parenteral or mucous-membrane route to blood or body fluids from patients with AIDS. Weekly Epidemiological Record 1985;24:186-7. (Based on MMWR 1984;34:7.)

119 McCray E, Winslow N, Solomon SL, et al. Prospective evaluation of health care workers with parenteral or mucous membrane exposure to blood from patients with AIDS, United States: an update. In: Proceeding of the International Conference on AIDS, Atlanta: Department of Health and Human Resources and the World Health Organisation, 1985:45.

120 Curran JW, Morgan M, Hardy AM, Jaffe HW, Darrow WW, Dowdle WR. The epidemiology of AIDS: current status and future prospects. Science 1985;229:1352-7.

121 Anonymous. An evaluation of the acquired immunodeficiency syndrome (AIDS) reported in health care personnel-United States. $M M W R$ 1983;32:358-60.

122 Adler MV, Weller IVD. AIDS: sense not fear. Br Med J 1984;288:1177-8

123 Anonymous. Needlestick transmission of HTLV-III from a patient infected in Africa. Lancet 1984;ii:1376-7.

124 Belani A, Dutta D, Roseu S, et al. AIDS in a hospital worker. Lancet 1984;i:676.

125 McEvoy MB, Galbaraith NS. SIDA y trabajadores sanitarios. Lancet 1984;5:294. (Spanish edition.)

126 Weiss SH, Saxinger WC, Rechtman D, et al. HTLV-III infection among health care workers: association with needle-stick injuries. JAMA 1985;254:2089-93.

127 Anonymous. Evaluation of human T-lymphotropic virus type III/ lymphadenopathy-associated virus infection in health-care personnelUnited States. MMWR 1985;34:575-8.

128 Communicable Disease Surveillance Centre. Communicable disease report. Weekly Epidemiological Record 1985;85:52.

129 Gerberding JL, Moss AR, Bryant CE, et al. Risk of acquired immune deficiency syndrome (AIDS) virus transmission to health care workers. In: Abstracts of the 25th Interscience Conference on Antimicrobial Agents and Chemotherapy, Washington: American Society of Microbiology, 1985;25:131.

130 Shanson DC, Evans R, Lai L. Incidence and risk of transmission of HTLVIII infection to staff at a London Hospital 1982-5. J Hosp Infect 1985;6 suppl c:15-22.

131 Gerberding JL (personal communication). Cited by: Sande MM Transmission of AIDS. The case against casual contagion. $N$ Engl J Med 1986;314:380-2.

132 Jones P, Hamilton P. HTLV-III antibodies in haematology staff. Lancet $1985 ; \mathrm{i}: 217$.

133 Hirsh MS, Wormser GP, Schooley RT, et al. Risk of nosocomial infection with human T-cell lymphotropic virus III (HTLV-III). N Engl J Med
$1985 ; 312: 1-4$

134 Velardo A, García de Pesquera F, Merino M, Leal M. Ausencia de anticuerpos frente al virus del sindrome de inmunodeficiencia adquirida en personal hospitalario en contacto con grupos de riesgo. Medicina Clinica 1986;86:132.

135 Gerberding JL, Hopewell PC, Kaminsky LS, Saude MA. Transmission of hepatitis B without transmission of AIDS by accidental needlestick. $N \subseteq$ Engl J Med 1985;312:56-7.

136 Miller D, Jeffries DJ, Green J, Harris JRW, Pinching AJ. HTLV-IIl: should $\overline{\mathcal{G}}$ testing ever be routine? $\mathrm{Br}$ Med J 1986;292:941-3.

137 Sande MA. Transmission of AIDS. The case against casual contagion. $N$ 으 Engl J Med 1986;314:380-2.

138 Conte JE, Hadley WK, Sande M. Infection-control guidelines for patients with the acquired immunodeficiency syndrome (AIDS). N Engl $J$ Med $\vec{O}$ 1983;309:740-4.

139 Center for Disease Control. Acquired immune deficiency syndrome (AIDS): precautions for clinical and laboratory staffs. $M M W R$ 1982;31:577-80. $\omega$

140 Center for Disease Control. Acquired immunodeficiency syndrome (AIDS): precautions for health-care and allied professionals. MMWR 1983; 32:450-1.

141 Spire B, Barre-Sinoussi F, Montagnier JC. Inactivation of a new retrovirus:(lymphadenopathy-associated virus) by various agents (chemical $A$ disinfectants). Lancet 1984;ii:899-901.

142 Anonymous. Recommendations for preventing possible transmission of ${ }^{-}$ lymphadenopathy-associated virus/human T-lymphotropic virus type III from tears. Weekly Epidemiological Record 1985;38:293-4.

143 Martin LS, McDougal JS, Loskoski SL. Disinfection and inactivation of the human T-lymphotropic virus type III/lymphadenopathy-associated virus. J Infect Dis 1985;152:400-3.

144 Center for Disease Control. Recommendations for preventing transmissionc of infection with human T-lymphotropic virus type III lymphadenopathy-associated virus in the workplace. $M M W R$ 1985;34:681-95.

145 Shanson DC, Sanderson PJ, eds. Proceeding of a hospital infection societyœ symposium of the acquired immune deficiency syndrome. J Hosp Infect. 1985;6 suppl:1-80.

146 Dinsdale RCW. Viral hepatitis, AIDS and dental treatment. London: British Dental Journal, 1985

147 Confederation of Health Service Employees (OHSE). Guidelines for health staffs dealing with patients suffering from acquired immune deficiency syndrome (AIDS) or with AIDS virus. Banstead: COHSE, 1985.

148 Miller D, Weber J, Green J. The management of AIDS patients. Basingstoke: MacMillan, 1986.

149 Das B, Dilworth PH, Gamlen TR, Winton MRJ. Risk of Aids to health care workers. Br Med J 1986;292:898.

150 Reitman M, Wedum AG. Microbiological safety. Public Health Reports 1956;71:659-65.

151 Wedum AG. Laboratory safety in research with infectious aerosols. Public Health Reports 1964;7:619-33.

152 Kenny MT, Sabel FL. Particle size distribution of Serratia marcescens $O$ aerosols created during common laboratory procedures and simulated $\frac{(\mathrm{D}}{3}$ laboratory. Appl Microbiol 1968;8:1146-50.

153 Howie J, Collins $\mathrm{CH}$, Darlow HM, et al. Code of practice for the prevention of infection in clinical laboratories and post-mortem rooms. London:HMSO, 1984.

154 Whitehead, JEM. Manual de bioseguridad en el laboratorio. Ginebra: Organización Mundial de la Salud, 1983. 